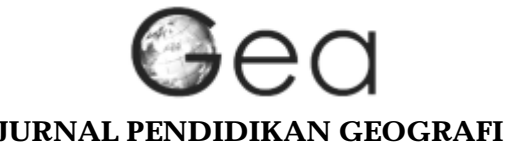

\title{
KONTRIBUSI PEMAHAMAN KONSEP GEOGRAFI TERHADAP SIKAP DAN PERILAKU KERUANGAN PESERTA DIDIK SMA DI KOTA CIREBON
}

\author{
${ }^{1} \mathrm{~N}$ uansa Bayu Segara, ${ }^{2} \mathrm{G}$ urniwan Kamil, P., ${ }^{3}$ Enok Maryani \\ Jurusan Pendidikan IPS Ekonomi, FKIP Unswagati, Cirebon, \\ email: nuansasegara@yahoo.co.id \\ 2Jurusan Pendidikan Geografi, FPIPSUPI, email: gurniwan_kamil@yahoo.com \\ 3Jurusan Pendidikan Geografi, FPIPS UPI, email: emaryani@yahoo.com
}

\begin{abstract}
ABSTRAK
Proses pembelajaran geografi mengalami pergeseran orientasi, pembentukan sikap dan perilaku keruangan tidak lagi menjadi prioritas, karena prioritas utama pembelajaran geografi saat ini untuk meluluskan peserta didik dari ujian nasional. Begitu pula yang terjadi di Kota Cirebon, padahal dal am lima tahun terakhir ini Kota Cirebon berkembang pesat sebagai pusat pertumbuhan. Sehingga sikap dan perilaku penduduknya dalam memperlakukan ruang harus dibentuk sejak dini dengan proses pembelajaran geografi. Pemahaman konsep merupakan salah satu aspek yang dibentuk dalam proses pembelajaran geografi, sehingga perlu diketahui seberapa besar pemahaman konsep berkontribusi terhadap sikap dan perilaku keruangan peserta didik?Untuk menjawab pertanyaan penelitian tersebut perlu mengukur variabel-variabel yang terkait. Pemahaman konsep geografi diukur dengan instrumen tes dengan indikator translasi, interpretasi dan ekstrapolasi yang dikaitkan dengan konsep lokasi, jarak dan interaksi. Sedangkan untuk mengukur sikap dan perilaku keruangan menggunakan instrumen non tes dengan skala rating.Hasil identifikasi dan analisis data didapatkan beberapa hal yang menjawab pertanyaan penelitian. Pemahaman konsep geografi berkontribusi rendah terhadap sikap dan perilaku keruangan. Selain itu, sikap keruangan berkontribusi cukup rendah terhadap perilaku keruangan. Hasil tersebut membuktikan teori postulat konsistensi tergantung bahwa hubungan sikap dan perilaku sangat situasional sehingga banyak faktor yang mempengaruhi.
\end{abstract}

Kata kunci: pemahaman konsep, sikap keruangan, perilaku keruangan

\section{PENDAHULUAN}

\section{LatarBelakangM asalah}

Perubahan ruang perlahan terjadi di Kota Cirebon, kondisi lingkungan fisik, ekonomi dan sosial-budaya mengalami perubahan yang konstan. Kemajuan di bidang perdagangan dan jasa menjadi pemicu terjadinya perbedaan kondisi sosial dan budaya yang berdampak pada kehidupan peserta didik di Kota Cirebon. Hal tersebut perlu disadari betul oleh pendidikan geografi di persekolahan sebagai tujuan pembelajaran yang berbasis sikap dan perilaku, sehingga peserta didik mampu secara bijak berperilaku atau dalam pengambilan keputusan terhadap perubahan ruang di 
Kota Cirebon. Sehingga orientasi pembelajaran geografi untuk meningkatkan aspek kognitif saja harus dirubah.

A wal tahun 2012K ota Cirebon mengalami banjir yang dalam 50 tahun sebelumnya tidak terjadi. Kepanikan sempat terjadi beberapa saat di Kota Cirebon, Iuapan saluran drainase menjadi salah satu penyebab banjir yang terjadi di pusat kota itu. Banjir yang terjadi di Kota Cirebon itu harus menjadi momentum dari pembelajaran geografi untuk mengajarkan perilaku dan sikap yang peka terhadap perubahan fisik kota yang peserta didik tempati. Peserta didik dengan pembelajaran geografi harus mampu mengkondisikan dirinya ketika berinteraksi dengan alam, sehingga sebagai manusia mampu memanfaatkan kondisi sekitar untuk kemajuan dirinya.

Pendidikan geografi dapat menjadi senjata untuk menuntaskan masalah-masalah lingkungan yang dialami dunia dan Indonesia pada khususnya. Pendidikan pada dasarnya diperlukan untuk merubah perilaku. Pengetahuan akan yang diperlukan untuk meningkatkan wawasan atau perilaku keruangan manusia. Perilaku keruangan ini didasari oleh aspek kognitif individu berupa pengetahuan, dari pengetahuan inilah akan menghasilkan suatu sikap, menurut beberapa ahli sikap akan mempengaruhi perilaku individu namun di sisi lain ada pula yang menganggap tidak selamanya perilaku didasari oleh sikap.

Pembelajaran geografi yang berorientasi terhadap sikap dan perilaku keruangan menjadi terlupakan ketika geografi menjadi salah satu mata pelajaran yang masuk kedalam ujian nasional. Orientasi pembelajaran geografi di Kota Cirebon terfokus untuk meluluskan peserta didik dalam ujian nasional. Sehingga pembentukan sikap dan perilaku keruangan terabaikan.

Pembentukan sikap dan perilaku keruangan ini seharusnya menjadi tanggung jawab pendidikan geografi. Berdasarkan tujuan itulah guru geografi sebagai ujung tombak pendidikan geografi di persekolahan seharusnya memiliki peran penting dalam meningkatkan sikap dan perilaku keruangan siswa. Abdurachman (1988:76) mengatakan bahwa pengetahuan dan persepsi lingkungan berpengaruh terhadap perilaku keruangan individu. Selanjutnya tindakan keruangan manusia tidaklah bersifatmendadak, tetapi berlangsunglamasebagai pernyataan dari prosesatau sistem. Proses dan sistem ini merupakan perwujudan dari tujuan pendidikan geografi.

\section{RumusanM asalah}

Kemampuan spasial kognitif akan mempengaruhi sikap dan perilaku keruangan peserta didik. Aspek kognitif yang akan diukur dalam penelitian ini adalah pemahaman konsep geografi peserta didik. Maka dari identifikasi masalah tersebut timbul pertanyaan penelitian: 1) Seberapa besar kontribusi pemahaman konsep geografi terhadap sikap keruangan peserta didik SMA di Kota Cirebon? 2) Seberapa besar kontribusi pemahaman konsep geografi terhadap perilaku keruangan peserta didik SMA di Kota Cirebon? 3) Seberapa besar kontribusi sikap keruangan terhadap perilaku keruangan peserta didi SMA di Kota Cirebon?

\section{METODE PENELITIAN}

Penelitian ini menggunakan penelitian survei dengan menggunakan analisis korelasi. Korelasi yang digunakan terdiri dari dua jenis, yang pertama adalah statistik non parametrik dan statistik parametrik.Penelitian ini menggunakan pendekatan kuantitatif, pendekatan kuantitatif tidak lepas dari pengujian hipotesis yang didasari 
atas nilai yang dihasilkan dari perhitungan statistik. Terdapat tiga variabel dalam penelitian ini, variabel $\mathrm{X} 1$ adalah pemahaman konsep geografi, variabel $\mathrm{Y} 1$ adalah sikap keruangan dan variabel $Y 2$ adalah perilaku keruangan.

Populasi dalam penelitian ini adalah peserta didik SMA kelas XI di Kota Cirebon yang berjumlah 1812 dengan menggunakan rumus Taro Yamane dan tingkat kepercayaan $92 \%$ didapat jumlah sampel sebanyak 144 peserta didik. Selanjutnya sampel tersebut diproporsionalkan berdasarkan jumlah peserta didik yang ada di SM A N egeri dan SM A Swasta, selanjutnya diproporsionalkan lagi berdasarkan jumlah peserta didik SMA kelas XI di setiap sekolah sampel.

Instrumen penelitian yang digunakan untuk mengukur variabel pemahaman konsep geografi, sikap keruangan dan perilaku keruangan sudah melalui tahapan validasi dan reliabilitas. Validasi Instrumen tespemahaman konsep geografi dilakukan dengan menghitung nilai biserial, selain itu instrumen ini telah diuji daya pembeda, efektifitas option dan tingkat kesukaran. Reliabilitas insturmen pemahaman konsep geografi menggunakan metode split-half one trial test spearman brown dengan hasil 0,705 yang menunjukan bahwa instrumen pemahaman konsep geografi reliabel untuk pengambilan data. Selanjutnyainstrumen non tes sikap dan perilaku keruangan yang menggunakan metode validasi dengan melihat nilai pearson correlation dan reliabilitas dengan melihat nilai crossbach alfa.

Perhitungan statistik yang digunakan untuk mencari hubungan antar variabel dalam penelitian ini terdiri dari dua jenis. Non parametrik Spearman correlation digunakan untuk mencari hubungan antara pemahaman konsep geografi terhadap sikap dan perilaku keruangan. Statistik parametrik pearson correlation digunakan untuk mengetahuihubungan sikap dan perilaku keruangan.

\section{HASIL DAN PEMBAHASAN}

Setelah memperoleh data dari lapangan selanjutnya dilakukan pemasukan data dan tabulasi data. Sebelum perhitungan statistik dilakukan, perlu adanya uji normalitas data. Pengujian ini dimaksudkan untuk mengetahui data yang didapat berdistribusi normal atau tidak. Uji normalitas data dalam penelitian ini dengan melihat nilai ratio skewness dan nilai ratio kurtosis juga melihat histogram data. Hasil uji normalitas data dengan nilai yang disebutkan diatas menunjukan keseluruhan data berdistribusi normal. Tahap selanjutnyaadal ah pengolahan data untuk menjawabsemuapertanyaan penelitian. Namun sebelum itu perlu diketahui hasil data per variabel yang diolah secara statistik persentase.

\section{Tingkat Pemahaman Konsep G eografi}

Pemahaman konsep geografi yang diuji dalam penelitian ini memiliki tiga indikator yang terkait dengan tiga konsep yang diajukan. Indikator yang tersebut adalah interpretasi, translasi dan ekstrapolasi yang masing-masing indikator terkait dengan konsep lokasi, jarak dan interaksi dengan lingkungan. Hasil dari tingkat pemahaman konsep geografi dapat dilihat melalui tabel berikut ini.

Secarakeseluruhan tingkat pemahaman konsep geografi pesertadidik SMA di Kota Cirebon berdasarkan hasil penelitian tersebar ke beberapa tingkatan. Sebagian kecil peserta didik SMA di Kota Cirebon yang memiliki tingkat pemahaman sangat rendah. Sel anjutnya kurang dari setengah peserta didik berada di tingkatan pemahaman tinggi yang sebesar $40 \%$. Peserta didik kelas XI IPS di Kota Cirebon kurang dari setengah 
memiliki pemahaman konsep geografi yang tinggi. Berarti pemahaman pembelajaran geografi di SMA Kota Cirebon sudah menyentuh aplikasi dalam kehidupan dan karakteristik dikondisi lingkungan sekitar. Namun sebagian besar peserta didik di Kota Cirebon masih masuk kedalam kategori tingkat pemahaman geografi sangat rendah, rendah dan cukup rendah, sehingga pembelajaran geografi yang menyentuh aspek pemahaman harus digunakan oleh guru geografi SMA di Kota Cirebon.

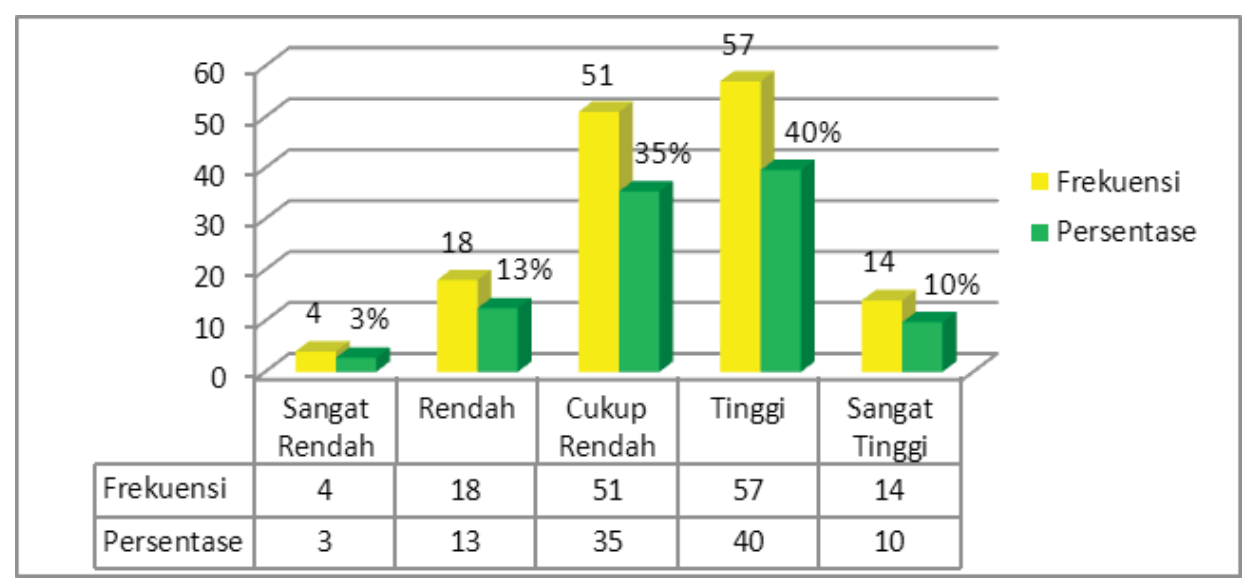

Sumber : Hasil Penelitian 2012

Gambar 1. Grafik dan Tabel Tingkat Pemahaman Konsep Geografi

\section{Tingkat Sikap Keruangan}

Sikap keruangan merupakan indikasi awal dari terbentuknya perilaku keruangan. Si kap keruangan juga salah satu hasil dari pembentukan dalam proses kognitif. Dalam pembelajaran geografi pun, seharusnya sikap menjadi salah satu bahan evaluasi pendidikan. Sikap merupakan modal awal dari manusia untuk bertindak, itulah yang disampaikan oleh beberapa ahli psikologi dalam buku sikap dan perilaku. Berikut ini tingkat sikap keruangan berbentuk grafik.

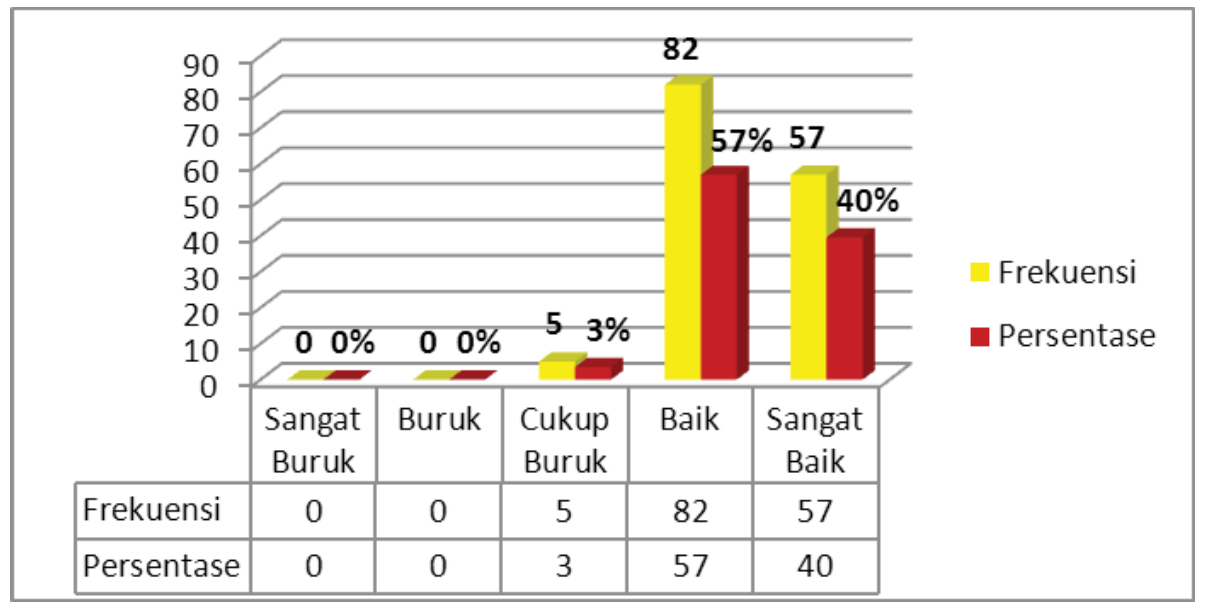

Sumber : Hasil Penelitian 2012

Gambar 2. Grafik dan Tabel Tingkat Sikap Keruangan Peserta Didik SMA Kota Cirebon 
Hasil positif diperlihatkan grafik tingkat sikap keruangan, terlihat peserta didik di Kota Cirebon memiliki sikap keruangan yang baik. Lebih dari setengah peserta didik memiliki sikap keruangan baik atau $57 \%$ dari keseluruhan peserta didik. Selanjutnya lebih dari setengah peserta didik yang lain memiliki sikap keruangan sangat baik berjumlah atau sebesar $40 \%$ dari keseluruhan peserta didik SM A kelas IX IPS di Kota Cirebon. Hasil tersebut menunjukan bahwa sikap keruangan peserta didik SMA kelas IX IPS di Kota Cirebon termasuk kedalam kategori baik. Proses kognitif sangat dipengaruhi oleh personality variabel dan komunitas (faktor budaya) sehingga pembentukan sikap tidak hanya dari pemahaman konsep geografi saja.

\section{Tingkat Perilaku Keruangan}

Perilaku keruangan yang diukur dalam penelitian ini terkait dengan lokasi, jarak dan interaksi dengan lingkungan. Lokasi dan jarak sangat dominan dalam penelitianpenelitian perilaku keruangan sebelumnya, namun untuk interkasi dengan lingkungan masih jarang dilakukan. Semua pernyataan dalam instrumen sudah diaplikasikan sesuai dengan kondisi geografis Kota Cirebon. Pernyataan dalam instrumen perilaku keruangan ini pun sudah di kaitkan dengan penyataan yang ada dalam instrumen sikap keruangan.

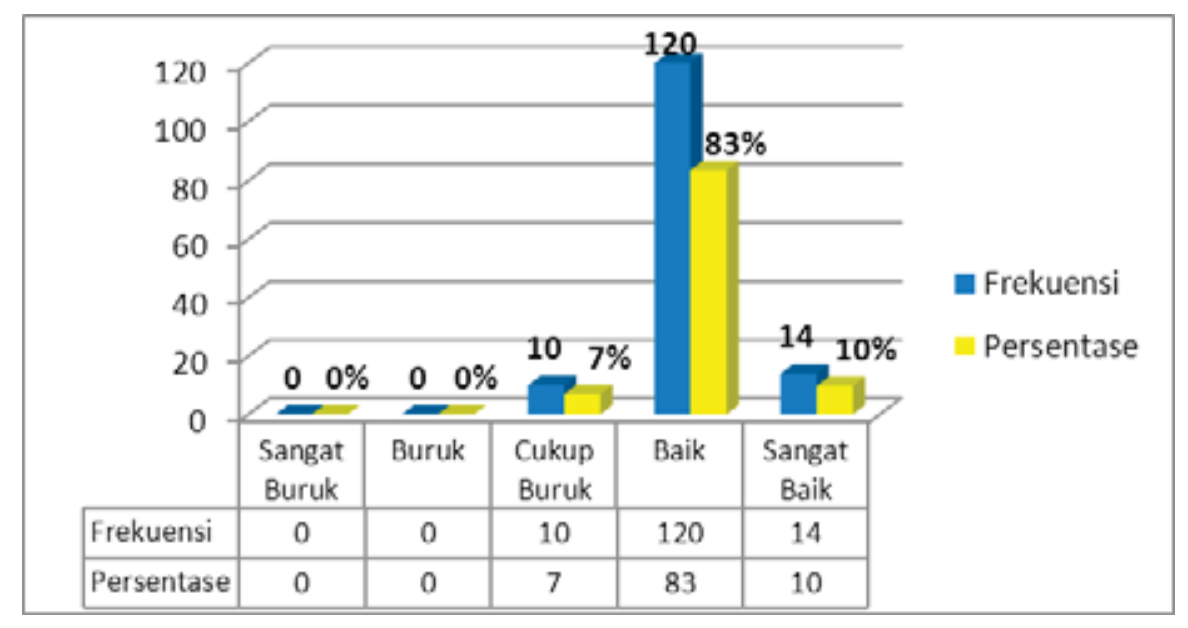

Sumber: Hasil Penelitian 2012

Gambar 3. Grafik dan Tabel Tingkat Perilaku KeruanganPeserta Didik SMA di Kota Cirebon

Tingkat perilaku keruangan peserta didik SMA kelas XI IPS di Kota Cirebon terlihat baik, karena sebagian besar peserta didik yang memiliki perilaku keruangan baik dan sebagian kecil peserta didik yang memiliki perilaku keruangan sangat baik. Sedangkan hanya sebagian kecil lain dari peserta didik SMA di Kota Cirebon yang memiliki perilaku keruangan cukup rendah. Perilaku keruangan yang ditunjukan oleh grafik ini didominasi oleh perilaku yang baik dan sangat baik. Proses kognitif diasumsikan berpengaruh terhadap perilaku keruangan, namun tidak hanya proses kognitif saja melainkan banyak faktor yang mempengaruhinya.

Peserta didik SMA di Kota Cirebon harus memiliki pemahaman konsep yang baik, karena pemahaman konsep yang sudah diaplikasikan dalam kehidupan sehari-hari 
dapat menjadi soft skills yang bermanfaat. Peserta didik yang memiliki pemahaman konsep geografi terkait ruang yang baik akan memiliki kemampuan identifikasi, prediksi dan judgement terhadap ruang yang ada disekitarnya. Kemampuan dalam pengambilan keputusan terhadap ruang sangat berguna dalam kehidupan manusia, pengambilan ruteketikaberpergian, memperlakukanlingkungan agar tidakmerugikan diri sendiri dan orang lain, tanggap terhadapa bahaya dan penanggulangan bencana al am, semua hal tersebut merupakan pentingnya perilaku keruangan yang didukung oleh proses kognitif yang baik.

\section{Kontribusi Pemahaman Konsep Geografi terhadap Sikap Keruangan}

Perhitungan statistik yang digunakan untuk menguji hubungan antara variabel X1 dan Y l ini dengan menggunakan korelasi spearman. Berikut ini tabel yang menunjukan hasil perhitungan nilai korelasi spearman antara variabel $\mathrm{X} 1$ dan $\mathrm{Y} 1$.

Nilai korelasi spearman antara variabel pemahaman konsep geografi (X1) dan sikap keruangan (Y1) peserta didik SMA kelas IX Kota Cirebonmemiliki nilai koefisien korelasi 0,249, berarti dapat diinterpretasikan bahwa tingkat hubungan antara pemahaman konsep geografi dengan sikap keruangan peserta didik rendah. Signifikasi hubungan antara variabel $\mathrm{X} 1$ dengan $\mathrm{Y} 1$ telah dihitung dan mendapatkan nilai 0,003 ini berarti hubungan antara dua varibel signifikan, karena nilai signifaksi $<0,05$.

Selanjutnya akan dicari nilai kontribusi variabel pemahaman konsep geografi terhadap sikap keruangan peserta didik. Nilai koefisien determinan (KD) dari nilai koefisien korelasi 0,249 adalah 6,2\%. Dapat dinyatakan bahwa pemahaman konsep geografi memberikan kontribusi sebesar 6,2\% terhadap sikap keruangan, selebihnya dipengaruhi oleh variabel lain yang tidak dijelaskan dalam penelitian ini. Pertanyaan penelitian yang mempertanyakan berapa besar kontribusi pemahaman konsep geografi terhadap sikap keruangan peserta didik SM A di Kota Cirebon telah terjawab. Kontibusi pemahaman konsep geografi terhadap sikap keruangan adalah sebesar $6,2 \%$.

\section{Kontribusi Pemahaman Konsep G eografi terhadap Perilaku Keruangan}

Pengujian korelasi variabel $\mathrm{X} 1$ dengan $\mathrm{Y} 2$ dengan korelasi spearman karena jenis data dari kedua variabel tersebut berbeda. Variabel pemahaman konsep geografi X1 berjenis data ordinal sedangkan variabel perilaku keruangan berjenis data rating scale. Berikut ini tabel yang menunjukan nilai korelasi antara variabel $\mathrm{X} 1$ dengan $\mathrm{Y} 2$.

Berdasarkan hasil perhitungan, nilai koefisien korelasi antara variabel $\mathrm{X} 1$ dengan Y2 sebesar 0,227 menunjukan bahwa hubungan tingkat pemahaman konsep geografi dengan perilaku keruangan rendah. Selanjutnya dilihat nilai signifikasi hubungan antara variabel pemahaman konsep geografi dengan variabel perilaku keruangan. Nilai signifikasi dari hubungan dua variabel ini sebesar 0,006. Karena nilai signifikasi $>0,05$ berarti hubungan dua variabel ini signifikan.

Selanjutnya untuk mengetahui seberapa besar kontribusi variabel $X 1$ kepada variabel Y2 dilakukan dengan mencari nilai koefisien determinasi (KD). Hasil kuadrat dari koefisien korelasi ( $r$ ) lalu dikalikan 100\% hasilnya koefisein determinasi dari hubungan dua variabel tersebut adalah sebesar 5,15\%. Hasil tersebut menunjukan kontribusi pemahaman konsep geografi terhadap perilaku keruangan sebesar 5,15\% selebihnya dipengaruhi oleh variabel lain. 


\section{Kontribusi Sikap Keruangan terhadap Perilaku Keruangan}

Perhitungan untuk mencari nilai koefisien korelasi dilakukan secara komputasi dengan menggunakan rumus korelasi product moment. Rumus korelasi product moment dipilih karenajenis data dari dua variabel ini berjenis datarating scal esehingga dapat dilakukan uji statistik parametrik. Kedua variabel memenuhi syarat untuk diujikan dengan rumus statistik korelasi product moment karena sudah dilakukan uji normalitas data. Hasilnya, baik variabel sikap keruangan ataupun variabel perilaku keruangan berdistribusi normal.

Berdasarkan hasil perhitungan yang ditujukan untuk mencari hubungan antara variabel sikap keruangan dan perilaku keruangan dengan menggunakan rumus statistik korelasi product moment didapatkan koefisien korelasi sebesar 0,414 dapat disimpulkan bahwa hubungan antara sikap dan perilaku keruangan cukup kuat.

Signifikasi hubungan dari hubungan kedua variabel ini sebesar 0,00 sehingga dapat disimpulkan bahwa hubungan antara variabel Y1 dan Y2 signifikan karena nilai signifikasi $\varangle 0,05$. Untuk mengetahui seberapa besar kontribusi variabel Y1 berpengaruh terhadap variabel Y2 perlu diketahui nilai koefisien determinasi. Hasil kuadrat dari nilai koefisien korelasi adalah sebesar 0,01715 sehingga jika dikali 100\% mendapatkan hasil 17,15\%. Artinya bahwa sikap keruangan memberikan kontibusi 17,15\% terhadap perilaku keruangan peserta didik SMA kelas IX IPS di Kota Cirebon. Hasil ini relatif lebih tinggi dibandingkan dengan dua pengujian kontribusi antar variabel sebelumnya.

Rendahnya kontribusi pemahaman konsep geografi terhadap terbentuknya sikap dan perilaku keruangan peserta didik dikarenakan banyak faktor yang mempengaruhi sikap dan perilaku keruangan peserta didik, bukan hanya satu variabel saja yaitu tingkat pemahaman konsep geografi namun banyak faktor yang ikut mempengaruhi. Keluarga dan lingkungan adalah contoh variabel lain yang mempengaruhi terbentuknya sikap dan perilaku keruangan peserta didik SMA kelas XI IPS di Kota Cirebon. Keluarga merupakan media pembentuk sikap dan perilaku keruangan yang paling awal dalam kehidupan peserta didik. Dalam pendidikan keluarga, sikap dan perilaku yang diajarkan atau dicontohkan oleh keluarga akan terbentuk dan menjadi pembiasaan perilaku yang dilakukan dalam kehidupan sehari-hari. Sehingga pendidikan keluarga sangat mungkin menjadi faktor lain dalam pembentukan sikap dan perilaku keruangan.

Selanjutnya lingkungan peserta didik memungkinkan untuk menjadi faktor lain dari terbentuknya sikap dan perilaku keruangan. Teori lain menyatakan bahwa proses kognitif diasumsikan dipengaruhi beberapa faktor yang terdiri dari phenomenal enviroment, personal environment, dan contextual environment, semua itu adalah faktorfaktor lingkungan yang membentuk sikap dan perilaku keruangan. Selanjutnya dari proses kognitif yang dipengaruhi oleh lingkungan akan membentuk persepsi. Sehingga saran untuk peneliti-peneliti berikutnya banyak sekali faktor dan indikator dalam membentuk sebuah perilaku keruangan peserta didik.

Sebelumnya penulis mengatakan bahwa faktor lain yang mungkin mempengaruhi sikap dan perilaku keruangan peserta didik berasal dari faktor eksternal dan faktor internal. Pembelajaran geografi seharunya memberikan kontribusi yang cukup besar terhadap pembentukan sikap dan perilaku keruangan peserta didik. Namun, hasil penelitian ini menunjukan bahwa pemahaman konsep geografi memberikan kontribusi yang rendah kepada sikap dan perilaku keruangan. 
Mengukur perilaku keruangan dan faktor-faktor yang mempengaruhinya tidak lepas dari faktor geografi fisik yang ada pada lingkungan tempat tinggal manusia tersebut. Lingkungan sosial juga tidak dapat diabaikan ketika akan mengukur sikap dan perilaku keruangan, sehingga untuk menemukan hasil yang memuaskan dalam meneliti sikap dan perilaku keruangan perlu analisis faktor secara komplek.

\section{SIM PULAN}

Pemahaman konsep geografi memberikan kontribusi terhadap sikap keruangan peserta didik SMA kelas XI IPS di Kota Cirebon. Kontribusi pemahaman konsep geografi terhadap sikap keruangan peserta didik SMA kelas XI IPS di Kota Cirebon rendah. Pemahaman konsep geografi memberikan kontribusi rendah terhadap perilaku keruangan peserta didik SMA kelas XI IPS di Kota Cirebon. Sikap keruangan memberikan kontribusi cukup rendah terhadap perilaku keruangan Pesertadidik SMA kelas XI IPS di Kota Cirebon. Hasil ini membuktikan teori hubungan antara sikap dan perilaku (teori postulat kontigensi tergantung), bahwa hubungan sikap dan perilaku sangat tergantung dengan situasional tertentu.

Kontribusi yang diberikan oleh pemahaman konsep geografi terhadap sikap keruangan sangat rendah. Sehingga penulis perlu merekomendasikan beberapa hal, rendahnya kontribusi diakibatkan sikap keruangan yang diukur dalam penelitian ini tidak menunjukan karakteristik ruang yang khas Kota Cirebon. Seharusnya sikap keruangan yang diukur sangat kental dengan karakteristik ruang yang akan diteliti.

Perilaku keruangan yang diukur seharusnya sangat terkait dengan karakteristik aspek-aspek keruangan Kota Cirebon, sehingga pemahaman konsep geografi yang sudah terkait karakteristik ruang Kota Cirebon akan memiliki kontribusi yang lebih besar terhadap perilaku keruangan.

Rekomendasi untuk peneliti lain terkait dengan hasil penelitian ini. Kontribusi pemahaman konsep geografi terhadap sikap keruangan peserta didik di Kota Cirebon sangat rendah, hal tersebut karena banyaknya faktor yang mempengaruhi sikap keruangan peserta didik, seperti image, sensation, perception, dan cultural environment. Sehingga hal tersebut merupakan kesempatan untuk peneliti lain meneliti variabelvariabel lain yang mempengaruhi sikap dan perilaku keruangan.

\section{DAFTAR PUSTAKA}

. Chapter IV : The D evelopment of Behaviour Space.

A bdurachman, Maman. (1988). Geografi Perilaku suatu Pengantar Studi tentang Persepsi Lingkungan. Jakarta : Depdikbud

Azwar, Saifuddin. (2011). Sikap M anusia Teori dan Pengukurannya Edisi 2 (Cetakan ke XV). Yogyakarta: Pustaka Pelajar.

Barliana, Syaom \& Maryani, Enok. (2008). Kontribusi Lingkungan Binaan dan Perilaku Spasial terhadap M odal Sosial Komunitas Penghuni dan Implikasinya terhadap Pendidikan IPS. Bandung: Jurnal Mimbar Pendidikan.

Cozby, C. Paul. (2009). M ethodes in Behavioural Research. Yogyakarta: Pustaka Pelajar.

Fadilla, Avin. (1999). BeberapaT eoriPsikologiLingkungan. Yogyakarta: Bulletin Psikologi.

Hadi, Saefull. (2006).G eografik omunikasi. Yogyakarta :UNY 
Hamzah.B.Uno.(2008). Profesi Problema, Solusi dan Reformasi Pendidikan di Indonesia, Cett.II. Jakarta: PT Bumi A ksara

James. M.; Huber, Richard; Mahnaz Moallem. (2001). Constructivism in Theory and Practice: Toward a Better U nderstanding. The High School Journal v84 no2 p35-53.

Kusnendi. (2010). A nalisis Jalur dengan A mos. Bandung : Rizqi Press.

Ningrum, Epon. (2009). Kompetensi Profesional Guru D alam Konteks Strategi Pembelajaran. Bandung: Buana Nusantara.

Sagala, Syaiful. (2010). Konsep dan M akna Pembelajaran U ntuk M embantu M emecahkan Problematika Belajar dan M engajar. Bandung: Alfabeta.

Santosa, Purbayu Budi \& Ashari. (2005). A nalisis Statistik dengan M icrosoft Excel dan SPSS. Yogyakarta: Andi.

Santoso, Singgih. (2011). Structural Equation M odeling (SEM ) Konsep dan A plikasi dengan A mos 18. Jakarta : PT. Elek Media Komputindo.

Shaughnessy, J. John; Zechmeister, B. Eugene; Zechmeister, S. Jeanne. (2007). M etode Penelitian Psikologi. Yogyakarta: Pustaka Pelajar.

Sumaatmadja, Nursid. (1997). M etodologi Pembelajaran Geografi. Jakarta: Bumi Aksara

Sumaatmadja, Nursid. (2005). M anusia Dalam Konteks Sosial Budaya dan Lingkungan Hidup. Bandung: Alfabeta.

Sunal, Cyhthia \& Hass, E M arry. (1993). Socaial Studies and TheElementary/middle School Student. Orlando: York Graphic Services.

O'Keefe \& Nylen . Chapter 2: Spatial Behaviour. Oxford University Press.

Pasya, Gurniwan, K. (2006). Geografi: Pemahaman Konsep dan M etodologi. Bandung: Buana Nusantara.

Mutakin, Awan. (2007). Geografi Perilaku Keragaman Perilaku Kelingkungan. Bandung

Walmsley \& Lewis. (1984). Human Geography: Behavioural Approaches. London: Longman

Yutina. (2006). Hubungan P engetahuan dengan Persepsi, Sikap dan M inat D al am Pengel olaan Lingkungan Hidup Pada Guru Sekolah D asar di Kota Pekanbaru. Pekanbaru: Jurnal Biogenesis 